\title{
Association of interleukin-18 gene polymorphism with body mass index in women
}

\author{
Hye-Lin $\mathrm{Kim}^{1+}{ }^{+}$, Sung One $\mathrm{Cho}^{2+}{ }^{+}$, Seon-Young Kim${ }^{1}$, Sung-Hoon Kim', Won-Seok Chung ${ }^{1}$, Seok-Hee Chung ${ }^{1}$, \\ Sung-Soo Kim', Seong-Gyu Ko ${ }^{1}$, Chang-Hyun Jeong ${ }^{1}$, Su-Jin Kim³ ${ }^{3}$ Seung-Heon Hong ${ }^{2}$ and Jae-Young Um*
}

\begin{abstract}
Background: Interleukin (IL)-18 is an important regulator of innate and acquired immune responses and has multiple roles in chronic inflammation and autoimmune disorders. Obesity is characterized by low- grade chronic inflammation. IL-18 has been suggested as an adipogenic cytokine that is associated with excess adiposity. The purpose of this study is to evaluate the relationship between $/ L-18$ gene polymorphisms ( $-137 \mathrm{G} / \mathrm{C}$ and $-607 \mathrm{C} / \mathrm{A}$ ) and obesity.

Methods: All 680 subjects were genotyped for the polymorphisms of IL-18 gene promoters (at positions $-137 \mathrm{G} / \mathrm{C}$ and -607 C/A) using a polymerase chain reaction (271 cases with BMl $\geq 25 \mathrm{~kg} / \mathrm{m}^{2}$ and 409 controls with BMl $<25 \mathrm{~kg} / \mathrm{m}^{2}$ ). A chi-square test was used to compare the genotype and allele frequencies between the cases and control populations.
\end{abstract}

Results: Analyses of the genotype distributions revealed that IL-18 -607 C/A polymorphism was associated with an increase in body mass index in obese women in the Korean population (chi $(2)=12.301, d f=2, p=0.015)$.

Conclusion: Carriage of the A allele at position -607 in the promoter of the $1 /$ - 18 gene may have a role in the development of obesity.

Keywords: Obesity, Interleukin-18, Polymorphism, Korean

\section{Background}

Obesity is increasing rapidly among women all over the world, and more women in fertile ages become overweight and obese [1]. Among all other problems, women who are obese have higher rates of amenorrhoea and infertility [1]. Over the past decade, research has associated obesity with inflammation; this association was first proposed in the seminal article by Hatamilsligil et al. [2]. In this article, tumor necrosis factor- $\alpha$ (TNF- $\alpha$ ) was shown to be constitutively expressed via adipose tissue, to be hyperexpressed in obesity, and to mediate insulin resistance in the major animal models of obesity. Furthermore, the neutralization of TNF- $\alpha$ with soluble TNF- $\alpha$ receptors resulted in the restoration of insulin sensitivity [2]. Thus, obesity is now characterized by a state of low- grade inflammation that is associated with the increase of cytokine production.

\footnotetext{
* Correspondence: jyum@khu.ac.kr

${ }^{\dagger}$ Equal contributors

${ }^{1}$ College of Oriental Medicine, Institute of Oriental Medicine, Kyung Hee University, 1 Heogi-dongDongdaemun-gu, Seoul 130-701, Republic of Korea Full list of author information is available at the end of the article
}

Adipose tissue, which is infiltrated by monocytes and macrophages in obesity, secretes numerous soluble mediators including adipokines such as adiponectin or leptin and many classical cytokines such as TNF- $\alpha$, interleukin (IL)-6, and IL-1 family members [3,4].

IL-18 has been suggested as an adipogenic cytokine [5] that is associated with excess adiposity [6]. Adipocytes from obese individuals produce higher levels of IL-18 compared with lean individuals and higher circulating IL-18 levels were observed in obese individuals and those with a high body mass index (BMI), insulin resistance, hypertriglyceridemia, and metabolic syndrome [6-9]. Deficiencies of $I L-18$ in mice $\left(I l 18^{-/-}\right)$led to the exhibition of late- onset obesity and insulin resistance [10]. Therefore, it has been hypothesized that the increased IL-18 concentrations have a pathophysiological role in obesity and metabolic syndromes.

Obesity has a strong genetic etiology involving numerous identified metabolic pathways and others not yet examined. IL-18 promoter polymorphisms have been associated with 
various inflammatory diseases, and three single nucleotide polymorphisms (SNPs) in the promoter of the $I L-18$ gene at the positions $-656 \mathrm{G} / \mathrm{T},-607 \mathrm{C} / \mathrm{A}$ and $-137 \mathrm{G} / \mathrm{C}$ have been identified. The functional significance of the two SNPs of the $C$ allele at position -607 and the $G$ allele at position -137 is attributed to the higher transcription and protein production of IL-18 $[11,12]$. In order to investigate the possible roles of the SNPs from the $I L-18$ gene promoter region $(-137 \mathrm{G} / \mathrm{C}$ and $-607 \mathrm{C} / \mathrm{A})$ in the development of obesity, the genetic polymorphisms of obese subjects were evaluated.

\section{Methods}

\section{Subjects}

Subjects were recruited consecutively from an obesity clinic at a Korean hospital; they were placed into an ongoing project that investigates candidate genes for obesity among the Korean population. The present study population included 680 individuals: 271 were chosen as cases $\left(\mathrm{BMI} \geq 25 \mathrm{~kg} / \mathrm{m}^{2}\right.$ ) and 409 were chosen as controls $\left(\right.$ BMI $\left.<25 \mathrm{~kg} / \mathrm{m}^{2}\right)$. The 271 cases $\left(\right.$ BMI $\left.\geq 25 \mathrm{~kg} / \mathrm{m}^{2}\right)$ consisted of 170 female subjects and 101 male subjects. All cases were nonsmokers and had no evidence of cancer, liver, renal, hematological disease or other metabolic disorders other than obesity. Details of the recruitment, body composition assessment, and biochemical analysis have been described previously [13]. All participants gave informed consent prior to participating in the research, which was approved by the local ethics committee in accordance with the Helsinki Declaration. Some subjects had participated in the research reported previously [13].

\section{Phenotype measurements Anthropometry}

Height (in $\mathrm{cm}$ ) and weight (in $\mathrm{kg}$ ) were measured in order to calculate the BMI as weight $(\mathrm{kg}) /$ height $(\mathrm{m})$ squared. The waist circumference (measured at the narrowest point above the hip) was divided by the circumference of the hip (measured at its greatest gluteal protuberance) in order to obtain the waist-to-hip ratio (WHR).

\section{Dual-energy X-ray absorptiometry}

The fat mass was determined using dual energy X-ray absorptiometry.

\section{Genotyping}

Genomic DNA was extracted from peripheral blood samples using the Exgene ${ }^{\mathrm{TM}}$ Blood SV Kit (GeneAll, Korea) as per the manufacturer's instructions. The concentration of DNA was estimated via absorbance at $260 \mathrm{~nm}$. The SNPs were noted at position $-137(\mathrm{G} / \mathrm{C})$ and $-607(\mathrm{C} / \mathrm{A})$ in the promoter region of the $I L-18$ gene, located at chromosome 11q22.2-q22.3. For the position -137-specific PCR, a common reverse primer and two sequence- specific forward primers were used to amplify the 261-bp product. A control forward primer was used to amplify the 446-bp fragment covering the polymorphic site as an internal positive amplification control. PCR was performed in a $20 \mu \mathrm{l}$ volume containing $0.5 \mu \mathrm{M}$ of one sequence specific primer and $-137 \mathrm{R}$, $0.3 \mu \mathrm{M}$ of $-137 \mathrm{CTRL}, 20 \mathrm{mM}$ Tris-HCl (pH 8.4), $50 \mathrm{mM} \mathrm{KCl}, 1.5 \mathrm{mM} \mathrm{MgCl}_{2}, 200 \mu \mathrm{M} / \mathrm{dNTPs}, 1 \mathrm{U}$ of Taq DNA polymerase, and $200 \mathrm{ng}$ genomic DNA. The cycling conditions were $2 \mathrm{~min}$ at $94^{\circ} \mathrm{C}$, followed by 5 cycles of $20 \mathrm{~s}$ at $94^{\circ} \mathrm{C}$ and $60 \mathrm{~s}$ at $67^{\circ} \mathrm{C}$ and 25 cycles of $20 \mathrm{~s}$ at $94^{\circ} \mathrm{C}$, $20 \mathrm{~s}$ at $61^{\circ} \mathrm{C}$ and $40 \mathrm{~s}$ at $72^{\circ} \mathrm{C}$ [14].

For the position -607-specific PCR, a common reverse primer and two sequence- specific forward primers were used to amplify the 196-bp product. A control forward primer was used to amplify the 301-bp fragment covering the polymorphic site as an internal positive amplification control. PCR was performed in a $20 \mu$ l volume containing $0.4 \mu \mathrm{M}$ of one sequence specific primer and $-607 \mathrm{R}$, $0.13 \mu \mathrm{M}$ of $-607 \mathrm{CTRL}, 20 \mathrm{mM}$ Tris- $\mathrm{HCl}(\mathrm{pH} 8.4)$, $50 \mathrm{mM} \mathrm{KCl}, 1.5 \mathrm{mM} \mathrm{MgCl} 2,200 \mu \mathrm{M} / \mathrm{dNTPs}, 1 \mathrm{U}$ of Taq DNA polymerase, and $200 \mathrm{ng}$ genomic DNA. The cycling

Table 1 Sequence-specific primers for G/C and C/A alleles and their PCR product sizes for positions -137 and -607 in the promoter of the IL-18 gene

\begin{tabular}{|c|c|c|}
\hline Sequence-specific Primers & Primer sequence & Product size (bp) \\
\hline \multicolumn{3}{|l|}{ G/C allele at position -137} \\
\hline Common reverse primer & 5'-AGGAGGGCAAAATGCACTGG-3' & \\
\hline forward primers 1 & 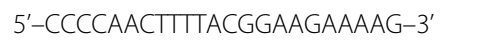 & 261 \\
\hline forward primers 2 & 5'-CCCCAACTाTACGGAAGAAAAC-3' & 261 \\
\hline Control forward primer & 5'-CCAATAGGACTGATTATTCCGCA-3' & 446 \\
\hline \multicolumn{3}{|l|}{$C / A$ allele at position -607} \\
\hline Common reverse primer & 5'-TAACCTCATTCAGGACTTCC-3' & \\
\hline forward primers 1 & 5'-GTTGCAGAAAGTGTAAAAATTATTAC-3' & 196 \\
\hline forward primers 2 & 5'-GTTGCAGAAAGTGTAAAAATTATTAA-3' & 196 \\
\hline Control forward primer & 5'-CTITGCTATCATTCCAGGAA-3' & 301 \\
\hline
\end{tabular}


conditions were $2 \mathrm{~min}$ at $94^{\circ} \mathrm{C}$, followed by 7 cycles of $20 \mathrm{~s}$ at $94^{\circ} \mathrm{C}, 40 \mathrm{~s}$ at $64^{\circ} \mathrm{C}$, and $40 \mathrm{~s}$ at $72^{\circ} \mathrm{C}$, and 25 cycles of $20 \mathrm{~s}$ at $94^{\circ} \mathrm{C}, 40 \mathrm{~s}$ at $57^{\circ} \mathrm{C}$, and $40 \mathrm{~s}$ at $72^{\circ} \mathrm{C}$ [14]. All PCR products were separated in $2 \%$ agarose gels stained with ethidium bromide. The sequence- specific primers for the position -137 and -607 - specific PCR are listed on Table 1.

\section{Statistical analysis}

A $X^{2}$ test was used to compare the genotype and allele frequencies between the cases and control populations. All statistical analyses were performed using SPSS v17.00 (SPSS Inc.) statistical analysis software. Hardy-Weinberg equilibrium was tested by chi-squared test and the haplotype analyses were done using HapAnalyzer version 1.0 (http://hap.ngri.go.kr). The associations between allele frequencies of SNPs and cases were estimated by computing the odds ratios and their 95\% confidence intervals with logistic regression analyses controlling for age. Genetic Power Calculator (http://pngu.mgh.harvard.edu/ purcell/ gpc) [15] was used to compute the statistical power of our sample. A $p$-value of less than 0.05 was considered statistically significant.

\section{Results}

\section{Clinical characteristics of subjects according to BMI}

The clinical characteristics of the cases according to their BMI are listed in Table 2. In order to obtain a better separation between phenotypes, the subjects were divided into three BMI groups: moderately overweight (BMI $25 \sim 26.9 \mathrm{~kg} / \mathrm{m}^{2}$ ), severely overweight (BMI $\left.27 \sim 29.9 \mathrm{~kg} / \mathrm{m}^{2}\right)$, and obese $\left(B M I \geq 30 \mathrm{~kg} / \mathrm{m}^{2}\right)$. As expected, the total cholesterol, triglyceride, fat mass, percentage of body fat $(\mathrm{PBF})$, and WHR increased in proportion to the BMI values.
Table 2 Characteristics of obese subjects according to BMI

\begin{tabular}{lllll}
\hline & \multicolumn{3}{l}{ BMI $\left(\mathbf{k g} / \mathbf{m}^{\mathbf{2}}\right)$} & \multirow{2}{*}{$\boldsymbol{p}^{\mathbf{a}}$} \\
\cline { 2 - 4 } & $\mathbf{2 5 \sim \mathbf { 2 6 . 9 }}$ & $\mathbf{2 7} \mathbf{2 9 . 9}$ & $\mathbf{3 0}$ & \\
\hline Age (year) & $28.9 \pm 11.2$ & $31.3 \pm 10.54$ & $33.1 \pm 12.9$ & .123 \\
Weight (kg) & $64.7 \pm 4.7$ & $71.3 \pm 6.2$ & $84.5 \pm 12.9$ & $<0.001$ \\
Height (cm) & $158.3 \pm 5.9$ & $159.0 \pm 5.9$ & $160.8 \pm 5.6$ & .029 \\
Total cholesterol (mg/dL) & $184.3 \pm 46.0$ & $184.2 \pm 36.6$ & $189.0 \pm 40.4$ & .728 \\
Triglyceride (mg/dL) & $117.0 \pm 112.4$ & $110.3 \pm 70.7$ & $136.3 \pm 112.8 .251$ \\
Fat mass (kg) & $23.3 \pm 2.3$ & $26.6 \pm 2.9$ & $36.4 \pm 8.1$ & $<0.001$ \\
PBF (\%) & $36.1 \pm 2.7$ & $37.0 \pm 5.0$ & $41.9 \pm 4.3$ & $<0.001$ \\
WHR & $0.89 \pm 0.03$ & $0.92 \pm 0.03$ & $0.99 \pm .07$ & $<0.001$ \\
\hline
\end{tabular}

Values are means \pm S.D.

$B M I=$ body mass index,$P B F=$ percentage of body fat, $W H R=$ Waist-to-hip ratio. ${ }^{\mathrm{a} B y}$ one-way Anova analysis (among BMI groups).

\section{Allele and haplotype frequencies in obese cases and controls}

The genotype and allele frequencies for $I L-18$ polymorphisms are summarized in Table 3 . The genotype frequencies were in agreement with the Hardy-Weinberg equilibrium. The power of the sample size was calculated to verify our data using a genetic power calculator [15]. The sample powers of the SNPs were more than 95\% $(\alpha=0.05$, genotype relative risk $=2$-fold $)$. For the -137 genotypes from the 271 cases with $\mathrm{BMI} \geq 25 \mathrm{~kg} / \mathrm{m}^{2}, 208$ had the GG type (76.8\%), 56 the GC type (20.7\%), and 7 the CC type (2.6\%) genotypes. Of the 409 controls with BMI $<25 \mathrm{~kg} / \mathrm{m}^{2}, 290$ had the GG type (70.9\%), 110 the GC type (26.9\%), and 9 the CC type (2.2\%) genotypes. Regarding the -607 genotypes, 69 of the 271 cases with BMI $\geq 25 \mathrm{~kg} / \mathrm{m}^{2}$ had the CC type (25.5\%), 157 the CA type $(57.9 \%)$, and 45 the AA type $(16.6 \%)$ genotypes. 94 of the 409 controls with BMI $<25 \mathrm{~kg} / \mathrm{m}^{2}$ were type CC

Table 3 Genotype frequencies of IL-18 gene promoter polymorphism of 271 cases and 409 controls

\begin{tabular}{|c|c|c|c|c|}
\hline & Cases (BMI $\geq 25), n(\%)$ & Controls (BMI <25),n (\%) & $x^{2}$ & $p^{a}$ \\
\hline Position -137 genotypeGG & $208(76.8)$ & $290(70.9)$ & 3.455 & .178 \\
\hline GC & $56(20.7)$ & $110(26.9)$ & & \\
\hline $\mathrm{CC}$ & $7(2.6)$ & $9(2.2)$ & & \\
\hline \multicolumn{5}{|l|}{ Alleles } \\
\hline G & $472(87.1)$ & $690(84.4)$ & 1.957 & .162 \\
\hline C & $70(12.9)$ & $128(15.6)$ & & \\
\hline Position -607 genotype & $69(25.5)$ & $94(23.0)$ & & \\
\hline \multicolumn{5}{|l|}{$\mathrm{CC}$} \\
\hline CA & $157(57.9)$ & $231(56.5)$ & 1.807 & .405 \\
\hline $\mathrm{AA}$ & $45(16.6)$ & $84(20.5)$ & & \\
\hline \multicolumn{5}{|l|}{ Alleles } \\
\hline C & $295(54.4)$ & $419(51.2)$ & 1.343 & .246 \\
\hline$A$ & $247(45.6)$ & $399(48.8)$ & & \\
\hline
\end{tabular}

${ }^{\mathrm{a}}$ By $\mathrm{x}^{2}$-test (2-sided). 
Table 4 Haplotype frequencies of IL-18 gene promoter polymorphism in case alleles and control alleles

\begin{tabular}{|c|c|c|c|c|c|c|}
\hline Haplotype & $-607 \mathrm{C} / \mathrm{A}$ & $-137 \mathrm{G} / \mathrm{C}$ & Cases (BMI $\geq 25), n(\%)$ & Controls (BMI <25),n (\%) & $x^{2}$ & $p^{\mathrm{a}}$ \\
\hline I & C & $G$ & $301(55.5)$ & $412(50.4)$ & 3.491 & .062 \\
\hline$\|$ & $C$ & C & $0(0)$ & $5(0.6)$ & 3.325 & .068 \\
\hline III & A & G & $182(33.6)$ & $284(34.7)$ & 0.188 & .665 \\
\hline IV & A & C & $59(10.9)$ & $117(14.3)$ & 3.380 & .066 \\
\hline Total & & & 542 & 818 & & \\
\hline
\end{tabular}

${ }^{\mathrm{a}}$ By $\mathrm{x}^{2}$-test (2-sided).

(23.0\%), 231 were CA (56.5\%), and 84 were AA (20.5\%) genotypes. No significant differences were observed in the genotype distribution or allele frequency between the cases and controls.

The haplotype frequencies were estimated based on genotypes of the $I L-18$ polymorphisms. The four haplotyes (haplotype I, II, III, and IV) of the $I L-18$ promoter at positions -607 and -137 were present in both cases $\left(\right.$ BMI $\left.\geq 25 \mathrm{~kg} / \mathrm{m}^{2}\right)$ and controls $\left(\right.$ BMI $\left.<25 \mathrm{~kg} / \mathrm{m}^{2}\right)$ and are presented in Table 4 . The frequencies of haplotypes I, II, III, and IV in the cases were $55.5 \%, 0 \%, 33.6 \%$, and $10.9 \%$, respectively. The frequencies of haplotypes I, II, III, and IV in the controls were $50.4 \%, 0.6 \%, 34.7 \%$, and $14.3 \%$, respectively. No significant differences were observed in the haplotype frequencies between the cases and the controls.

\section{Relationship between IL-18 polymorphism and BMI seen in obese women}

In order to further evaluate the association between the IL-18 polymorphisms and BMI, only female subjects, 170 of the 271 cases with $\mathrm{BMI} \geq 25 \mathrm{~kg} / \mathrm{m}^{2}$, were grouped according to their BMI range. The distributions of the GG, GC, and CC genotypes of position -137 and the distributions of the CC, CA, and AA genotypes of position -607 in these cases are shown in Table 5. A significant difference was found in the $-607 \mathrm{C} / \mathrm{A}$ genotype distribution among the BMI subgroups $\left(\chi^{2}=12.301, d f=2\right.$, $p=0.015$ ). Further analysis showed that the frequency of position -607 AA genotype was higher in a subgroup with $\mathrm{BMI} \geq 30 \mathrm{~kg} / \mathrm{m}^{2}$ than in both moderately overweight (BMI $25 \sim 26.9 \mathrm{~kg} / \mathrm{m}^{2}$ ) and severely overweight (BMI $\left.27 \sim 29.9 \mathrm{~kg} / \mathrm{m}^{2}\right)$ groups $\left(\chi^{2}=7.729, \quad d f=2\right.$, $p=0.021$ and $\chi^{2}=8.182, d f=2, p=0.017$, respectively). However, a difference in the distributions of the position -137 between BMI subgroups was not observed in the obese women.

\section{Discussion}

This study determined whether the promoter polymorphisms of $I L-18$ gene were associated with obesity and anthropometric parameters in obese women. Obesity is a complex metabolic disorder with a strong genetic component [16]. There are many candidate genes for obesity and its related phenotypes [16]. Most of these genes are candidates for obesity because their mutations cause rare genetic syndromes that affect the adipocyte differentiation [17]. However, the association between inflammatory cytokine genes and obesity has been studied less frequently when compared with other candidate genes. Thus, the association between the polymorphism of $I L-18$, a member of the $I L-1$ family, and obesity without metabolic disease was a primary focus of this study.

In this study, an association between the polymorphism in the $I L-18$ gene and BMI in women was found. The frequency of haplotype $\mathrm{I}$, which has the $\mathrm{C}$ allele at position -607 and the $G$ allele at position -137 , was higher in the subjects with $B M I \geq 25 \mathrm{~kg} / \mathrm{m}^{2}$ than in the control subjects with BMI $<25 \mathrm{~kg} / \mathrm{m}^{2}$, although the statistical significance was marginal. In addition, there was an apparent association between the $-607 \mathrm{C} / \mathrm{A}$ polymorphism in $I L-18$ and obesity in women.

The functional significance of the two SNPs of the C allele at position -607 and the $G$ allele at position -137 is attributed to the higher transcription and protein

Table 5 Frequencies of IL-18 gene promoter polymorphism according to BMI in female cases with BMI $\geq 25 \mathrm{~kg} / \mathrm{m}^{2}$ ( $\left.\mathrm{n}=170\right)$

\begin{tabular}{|c|c|c|c|c|c|}
\hline & BMI $\left(\mathrm{kg} / \mathrm{m}^{2}\right)$ & & & $x^{2}$ & $p^{a}$ \\
\hline & $25 \sim 26.9, \mathrm{n}(\%)$ & $27 \sim 29.9$, n (\%) & $\geq 30, n(\%)$ & & \\
\hline Position -137 & 34 (75.6) & $52(76.5)$ & $44(77.2)$ & 1.212 & .876 \\
\hline genotype & & & & & \\
\hline GG & & & & & \\
\hline GC & $9(20.0)$ & $15(22.1)$ & $12(21.1)$ & & \\
\hline CC & $2(4.4)$ & $1(1.5)$ & $1(1.8)$ & & \\
\hline Position -607 & $12(32.4)$ & $20(27.4)$ & $10(16.7)$ & & \\
\hline genotype & & & & & \\
\hline CC & & & & & \\
\hline CA & $22(59.5)$ & 45 (61.6) & $32(53.3)$ & 12.301 & .015 \\
\hline $\mathrm{AA}$ & $3(8.1)$ & $8(11.0)$ & $18(30.0)^{*,+}$ & & \\
\hline
\end{tabular}

a By $\mathrm{X}^{2}$-test (2-sided), among three BMI subgroups.

${ }^{*}$ By $X^{2}$-test (2-sided), $p=0.021, B M I 25 \sim 26.9 \mathrm{~kg} / \mathrm{m}^{2}$ group versus $\mathrm{BMI} \geq 30 \mathrm{~kg} / \mathrm{m}^{2}$ group.

${ }^{+}$By $X^{2}$-test (2-sided), $p=0.017, \mathrm{BMI} 27 \sim 29.9 \mathrm{~kg} / \mathrm{m}^{2}$ group versus $\mathrm{BMI} \geq 30 \mathrm{~kg} / \mathrm{m}^{2}$ group. 
production of IL-18 [11,12]. From the results presented here, it was observed that the frequency of haplotype I (the $\mathrm{C}$ allele at position -607 and the $\mathrm{G}$ allele at position -137) in the cases with BMI $\geq 25 \mathrm{~kg} / \mathrm{m}^{2}$ was higher than that in the controls with BMI $<25 \mathrm{~kg} / \mathrm{m}^{2}$. Therefore, it can be inferred that the mechanism by which the $I L-18$ gene polymorphism might influence obesity is related to different IL-18 synthesis, secretion, and activity. Indeed, several studies have shown elevated circulating IL-18 concentrations in subjects with obesity and insulin resistance [6,18-20]. In addition, serum IL-18 was increased in obese women, and it declined as body weight was lost [21].

The human $I L-18$ gene is located on chromosome 11q22.2-q23.3. Three SNPs in the promoter of the $I L-18$ gene at positions $-656 \mathrm{G} / \mathrm{T},-607 \mathrm{C} / \mathrm{A}$ and $-137 \mathrm{G} / \mathrm{C}$ have been identified. These promoter SNPs have been implicated as susceptibility loci for various diseases, including asthma [22], pulmonary tuberculosis [23], inflammatory bowel disease [24], Parkinson's disease [25], polycystic ovary syndrome [26], type I diabetes [27], and allergic disorders [28].

It now appears that obesity is associated with a lowgrade inflammation of the white adipose tissue resulting from the chronic activation of the innate immune system as the IL-1 family. Until recently, there were four members of the IL- 1 family: IL- $1 \alpha$, IL-1 $\beta$, IL- 1 receptor antagonist (IL-1ra), and IL-18 [29]. Previous studies have described an association between the $I L-1$ family gene polymorphism and obesity. Manica-Cattani et al. [30] and Lee et al. [16] reported that $I L-1 \beta$ polymorphism $(+3953 \mathrm{C} / \mathrm{T})$ is linked to the development of obesity. Song et al. [31] also suggested that $I L-1 \alpha$ polymorphism $(-889 \mathrm{C} / \mathrm{T})$ is associated with obesity in women. In addition, Strandberg et al. [32,33] demonstrated that the IL-1 system gene polymorphisms are associated with fat mass in men. The present study is the first approach in exploring the role of the $I L-18$ gene promoter polymorphism in the etiology of obesity in the Korean population. In addition, obesity is increasing rapidly among women all over the world. Obese women have a higher risk than nonobese women of infertility and pregnancy. The loss of as little as $5 \%$ of body weight is accompanied by an increase in ovulation rates and reduces biochemical abnormalities [34]. Therefore, the present study might allow targeted therapies to be developed to improve reproductive health in obese women.

\section{Conclusions}

In the present study, two polymorphisms in the promoter regions of the $I L-18$ gene were identified. An association between the $-607 \mathrm{C} / \mathrm{A}$ polymorphism and BMI were demonstrated in women. The results suggest that the $-607 \mathrm{C} / \mathrm{A}$ polymorphism of the $I L-18$ gene may have a role in the development of obesity.

\section{Competing interests}

The authors have declared that no conflict of interest exists.

\section{Authors' contributions}

Conceived and designed the experiments: JYU and SHH. Performed the experiments: HLK, SOC, SYK, and SJK. Analyzed and interpreted the data: JYU, SHK, WSC, SHC, SSK, CHJ, and SGK. Contributed Wrote the paper: HLK, SOC, and JYU. All authors read and authorized the final manuscript.

\section{Acknowledgements}

This work was supported by the Korea Science and Engineering Foundation (KOSEF) grant funded by the Korea government (MEST) (No. 2011-0006220).

\section{Author details}

${ }^{1}$ College of Korean Medicine, Institute of Korean Medicine, Kyung Hee University, 1 Heogi-dongDongdaemun-gu, Seoul 130-701, Republic of Korea. 2Department of Oriental Pharmacy, College of Pharmacy, Wonkwang University, Iksan, Jeonbuk 570-749, Republic of Korea. ${ }^{3}$ Department of Cosmeceutical Science, Daegu Hanny University 290, Yugok-Dong, Kyungsan 712-715, Republic of Korea.

Received: 29 February 2012 Accepted: 12 April 2012

Published: 24 April 2012

\section{References}

1. Linné Y: Effects of obesity on women's reproduction and complications during pregnancy. Obes Rev 2004, 5:137-143.

2. Hotamisligil GS, Shargill NS, Spiegelman BM: Adipose expression of tumor necrosis factor-alpha: direct role in obesity-linked insulin resistance. Science 1993, 259:87-91.

3. Tilg $H$, Moschen AR: Adipocytokines: mediators linking adipose tissue, inflammation and immunity. Nat Rev Immunol 2006, 6:772-783.

4. Moschen AR, Molnar C, Enrich B, Geiger S, Ebenbichler CF, Tilg H: Adipose and liver expression of interleukin (IL)-1 family members in morbid obesity and effects of weight loss. Mol Med 2011, 17:840-845.

5. Wood IS, Wang B, Jenkins JR, Trayhurn P: The pro-inflammatory cytokine $\mathrm{IL}-18$ is expressed in human adipose tissue and strongly upregulated by TNF alpha in human adipocytes. Biochem Biophys Res Commun 2005, 337:422-429.

6. Hung J, McQuillan BM, Chapman CM, Thompson PL, Beilby JP: Elevated interleukin-18 levels are associated with the metabolic syndrome independent of obesity and insulin resistance. Arterioscler Thromb Vasc Biol 2005, 25:1268-1273.

7. Skurk T, Kolb H, Müller-Scholze S, Röhrig K, Hauner H, Herder C: The proatherogenic cytokine interleukin-18 is secreted by human adipocytes. Eur J Endocrinol 2005, 152:863-868.

8. Esposito K, Pontillo A, Ciotola M, Di Palo C, Grella E, Nicoletti G, Giugliano D: Weight loss reduces interleukin-18 levels in obese women. $J$ Clin Endocrinol Metab 2002, 87:3864-3866.

9. Olusi SO, Al-Awadhi A, Abraham M: Relations of serum interleukin 18 levels to serum lipid and glucose concentrations in an apparently healthy adult population. Horm Res 2003, 60:29-33.

10. Netea MG, Joosten LA, Lewis E, Jensen DR, Voshol PJ, Kullberg BJ, Tack CJ, van Krieken H, Kim SH, Stalenhoef AF, van de Loo FA, Verschueren I, Pulawa L, Akira S, Eckel RH, Dinarello CA, van den Berg W, van der Meer JW: Deficiency of interleukin-18 in mice leads to hyperphagia, obesity and insulin resistance. Nat Med 2006, 12:650-656.

11. Kolesar L, Novota P, Krasna E, Slavcev A, Viklicky O, Honsova E, Striz I: Polymorphism of interleukin-18 promoter influences the onset of kidney graft function after transplantation. Tissue Antigens 2007, 70:363-368.

12. Im GJ, Choi J, Chang JW, Kim SJ, Kim HI, Jung HH: Expression of insulin-like growth factors in a mouse model of salicylate ototoxicity. Clin Exp Otorhinolaryngol 2010, 3:115-121.

13. Um JY, Chung HS, Song MY, Shin HD, Kim HM: Association of interleukin1 beta gene polymorphism with body mass index in women. Clin Chem 2004, 50:647-650.

14. Liu Y, Lin N, Huang L, Xu Q, Pang G: Genetic polymorphisms of the interlekin18 gene and risk of prostate cancer. DNA Cell Biol 2007, 26:613-618.

15. Purcell S, Cherny SS, Sham PC: Genetic Power Calculator: design of linkage and association genetic mapping studies of complex traits. Bioinformatics 2003, 19:149-150. 
16. Lee JH, Kwon YD, Hong SH, Jeong HJ, Kim HM, Um JY: Interleukin-1 beta gene polymorphism and traditional constitution in obese women. Int $\mathrm{J}$ Neurosci 2008, 118:793-805.

17. Arner P: Obesity-a genetic disease of adipose tissue? Br J Nutr 2000, 83(Suppl 1):S9-16.

18. Fischer CP, Perstrup LB, Berntsen A, Eskildsen P, Pedersen BK: Elevated plasma interleukin-18 is a marker of insulin-resistance in type 2 diabetic and non-diabetic humans. Clin Immunol 2005, 117:152-160.

19. Escobar-Morreale HF, Botella-Carretero Jl, Villuendas G, Sancho J, San Millán $\mathrm{J}$ : Serum interleukin-18 concentrations are increased in the polycystic ovary syndrome: relationship to insulin resistance and to obesity. J Clin Endocrinol Metab 2004, 89:806-811.

20. Leick L, Lindegaard B, Stensvold D, Plomgaard P, Saltin B, Pilegaard H: Adipose tissue interleukin-18 mRNA and plasma interleukin-18: effect of obesity and exercise. Obesity (Silver Spring) 2007, 15:356-363.

21. Bruun JM, Stallknecht B, Helge JW, Richelsen B: Interleukin-18 in plasma and adipose tissue: effects of obesity, insulin resistance, and weight loss. Eur J Endocrinol 2007, 157:465-471.

22. Ma Y, Zhang B, Tang RK, Liu Y, Peng GG: Interleukin-18 promoter polymorphism and asthma risk: a meta-analysis. Mol Biol Rep 2012, 39:1371-1376.

23. Han M, Yue J, Lian YY, Zhao YL, Wang HX, Liu LR: Relationship between single nucleotide polymorphism of interleukin-18 and susceptibility to pulmonary tuberculosis in the Chinese Han population. Microbiol Immunol 2011, 55:388-393.

24. Ben Aleya W, Sfar I, Habibi I, Mouelhi L, Aouadi H, Makhlouf M, AyedJendoubi S, Najjar T, Ben Abdallah T, Ayed K, Gorgi Y: Interleukin-18 gene polymorphisms in tunisian patients with inflammatory bowel disease. Digestion 2011, 83:269-274.

25. Xu X, Li D, He Q, Gao J, Chen B, Xie A: Interleukin-18 promoter polymorphisms and risk of Parkinson's disease in a Han Chinese population. Brain Res 2011, 1381:90-94.

26. Yang Y, Qiao J, Li MZ: Association of polymorphisms of interleukin-18 gene promoter region with polycystic ovary syndrome in chinese population. Reprod Biol Endocrinol 2010, 8:125-131.

27. Altinova AE, Engin D, Akbay E, Akturk M, Toruner F, Ersoy R, Yetkin I, Arslan M: Association of polymorphisms in the IL-18 and IL-12 genes with susceptibility to Type 1 diabetes in Turkish patients. J Endocrinol Invest 2010, 33:451-454.

28. Izakovicova Holla L, Hrdlicková B, Schüller M, Buckova D, Kindlova D, Izakovic V, Vasku A: Haplotype analysis of the interleukin-18 gene in Czech patients with allergic disorders. Hum Immunol 2010, 71:592-597.

29. Smith DE, Renshaw BR, Ketchem RR, Kubin M, Garka KE, Sims JE: Four new members expand the interleukin-1 superfamily. J Biol Chem 2000, 275:1169-1175.

30. Manica-Cattani MF, Bittencourt L, Rocha MI, Algarve TD, Bodanese LC, Rech R, Machado MM, Santos GF, Gottlieb MG, Schwanke CH, Piccoli JE, Duarte MF, Cruz IB: Association between interleukin-1 beta polymorphism (+3953) and obesity. Mol Cell Endocrinol 2010, 314:84-89.

31. Song JS, Jeong HJ, Kim SJ, Son MS, Na HJ, Song YS, Hong SH, Kim HM, Um $J Y$ : Interleukin-1alpha polymorphism $-889 \mathrm{C} / \mathrm{T}$ related to obesity in Korean Taeumin women. Am J Chin Med 2008, 36:71-80

32. Strandberg L, Lorentzon M, Hellqvist A, Nilsson S, Wallenius V, Ohlsson C, Jansson JO: Interleukin-1 system gene polymorphisms are associated with fat mass in young men. J Clin Endocrinol Metab 2006, 91:2749-2754.

33. Strandberg L, Mellström D, Ljunggren O, Grundberg E, Karlsson MK, Holmberg AH, Orwoll ES, Eriksson AL, Svedberg J, Bengtsson M, Ohlsson C, Jansson JO: IL6 and IL1B polymorphisms are associated with fat mass in older men: the MrOS Study Sweden. Obesity (Silver Spring) 2008, 16:710-713.

34. Norman JE: The adverse effects of obesity on reproduction. Reproduction 2010, 140:343-345.

\section{doi:10.1186/1477-7827-10-31}

Cite this article as: Kim et al:: Association of interleukin-18 gene polymorphism with body mass index in women. Reproductive Biology and Endocrinology 2012 10:31.

\section{Submit your next manuscript to BioMed Central and take full advantage of:}

- Convenient online submission

- Thorough peer review

- No space constraints or color figure charges

- Immediate publication on acceptance

- Inclusion in PubMed, CAS, Scopus and Google Scholar

- Research which is freely available for redistribution 